\title{
The Use of Malaysian English in the Work of Lloyd Fernando
}

\author{
Murooj Fareed Majeed \\ English Language and Literature, Taras Shevchenko National University of Kyiv, Ukraine \\ murooj_farid@yahoo.com
}

\begin{abstract}
The ongoing paper aims to study the use of Malaysian English lexis in creative writing by Lloyd. To be more accurate, the study aims to investigate the local language referents in the work of Lloyd Fernando in "Green is the colour". It is a sensitive novel about racial and religious tolerance set against the shadow of the 1969 racial riot in Kuala Lumpur where four main characters, good young people from different ethnic groups who become friends and even fell in love. To give this novel a characteristic of being more realistic, Lloyd Fernando uses lots of local words in his English novel, which lead this work to analyze these local lexis items according to categories made by Baskaran (2005).
\end{abstract}

Keywords : Malaysian English; Baskaran; merdeka; halal

\section{Introduction}

Malaysia is a land of natural grace and cultural activity. It is a multicultural and multilingual society where different ethnic groups live and practice their own tradition, religion and culture. It consists of three groups are the Malays, Chinese, and Indians arrived in Malaysia during the British colonial period. At that time English considered as the first language .It was the language of the ruling class, the Christian religion and the administration.

However, in post-British period, when Malaysia became independent in 1957, English was made the second language in conjunction with the promotion of Bahasa Malaysia as the national language (Ramakrishnan, Ismail, ibid, 2007).

Although English is the second language of Malaysia but it has continued to play an important role in Malaysia, it performs important functions in various fields such as literary, social, technology and commercial. It became deeply rooted in the country over a long period of time. A considerable amount of transfer from the local languages has occurred resulting in the English in Malaysia going through a process of nativization and emerging as what is known today as Malaysian English (Prema, Balan, 2012).

Various studies on the description of Malaysian English were conducted by Platt \& Webber (1980), Sridhar (1983), Trudgill \& Hannah (1982) and Baskaran (2005).

Platt \& Webber (1980:23) mentions that Malaysian English is a sequential series of subcategories like acrolect, mesolect and basilect. "Acrolect" is very similar to the first language but has a little local language specially in the field of lexis and phonology, "basilect" is Commonly used by uneducated speaker. And between these two categories is "mesolect" (Prema, Balan, 2012).

Trudgill \& Hannah (1982:100) clarifies that 'this kind of English language is different from the native English language speaker elsewhere in the world due to the existence of the local languages. Sridhar (1982:52-53) says that it is a process of 'absorbing of a strange symbol in the use of cultural and social context'.

To be cleared, what makes the Malaysian English differs from the standard British English is the existence of local words that don't appear in standard English and if they are, they may convey another meaning (Prema, Balan, 2012).

Malaysia has different languages but the most important one is Malay, which considers as the official language of Malaysia, other languages use in Malaysia are Indian languages 
like Tamil and Chinese dialects including Hokkien and Cantonese. All these languages play an important role in the nativising English in Malaysia (Baskaran, 2005).

From communicating, Malaysian English expanded into literary texts likewise. The lexis of Malaysian English was analyzed according to different Malaysian writers in English (Prema, Balan, 2012). such as the work of Llyod Fernando, Tan Twan and Rani Manicka the author of "Rice Mother" who settles down abroad but uses Malaysian English in her novel, also Tan Twan who uses Malaysian English words that reflect certain cultural group in Malaysia for example, "amah" "lao puo" refer to grandmother and wife .These words are from Chinese ethnic group in Malaysia. Another writer is Preeta Samarasan, who also lives abroad but uses Malaysian term in her writing to show her Malaysian English cultural background .The analysis of the use of Malaysian English lexis in these writer's work were covered in the thesis but here in this article the investigation will be on the use of Malaysian English lexis in the work of Lloyd Fernando 'Green is the Color'. The data will be grouped according to the categorization methods proposed by Baskaran (2005).

\section{Categories of Malaysian English Lexis by Baskaran}

Baskaran (1985) categorized Malaysian English lexis in two types

i). Local language referent (use of local lexicon in ME)

It indicates a native lexical items are absorbed into the standard English language providing it with the flavor of Malaysian English, also the mixture of language would give an easy way for communication (Prema, Balan, 2012).The shifting of local words can even happen with an existing English word but with the usage of different meaning in Malaysian English, which is a good way for establishing a national identity for all Malaysian races through the use of "Bahasa Malaya"

ii). Standard English lexicalisation (English lexemes with ME usage).

It indicates English lexemes uses in Malaysian English but it may convey another meaning.

Many researchers classify the Malaysian English into categories such as Tongue (1974) who classifies ME into two categories:first category uses by uneducated and in informal contexts, second category uses by educated and formal context, and Platt \& Weber (1980) categories ME into a) words from the native language, b) words taken from standard English but has different meaning in ME. After looking at these methods of categorization, the following work is going to be analyzed according to categories that made by Baskaran (2005) for the local word referent.

\section{Analyzing Malaysian English Lexis in the Work of Lloyd Fernando}

Malaysian English includes local words that shifted from the native language into the English language to form the Malaysian English. Many Malaysian writers use Malaysian English in their creative writing work .one of them is Lloyd Fernando who uses local words in his English novel. This article is going to investigate the use of these local words in Lloyd Fernando novel 'Green is the color' to the six sub categories that made by Baskaran (2005) for the local word referent.

a) Institutional concept

These are local words borrowed into ME, which have no equivalent in Standard English, for example halal 


\begin{tabular}{|l|l|l|}
\hline & Sentence/phrase & Meaning \\
\hline Halal & $\begin{array}{l}\text { Everything here is halal, you know. I } \\
\text { can make for you very fast (73) }\end{array}$ & Allowed by Islam \\
\hline
\end{tabular}

Halal is an international Muslim words .It means "accepted or allowed by Islam law". It is used by Muslim Malay, since Islam is the main religion in Malaysia .The author shows that this word is not used only among Muslim Malay ,but it also uses by Indian and Chinese in Malaysia ,thus when Sara went to a Chinese restaurant, the lady who works there ,told her that all the food here is Halal, which means that the Islamic form of slaughtering animals or poultry, dhabiha, involves killing through a cut to the jugular vein, carotid artery and windpipe. Animals must be alive and healthy at the time of slaughter and all blood is drained from the carcass. During the process, a Muslim will recite a dedication, known as tasmiya or shahada (Eardley, 2014). So if translated this sentence into the food is allowed it is gone be more sarcastic and comical .

b) Emotional and cultural loading

These are words that when translated to English are deprived of their cultural-bound connection, for example

\begin{tabular}{|l|l|l|}
\hline Word & Sentence/phrase & English equivalent \\
\hline cucu & $\begin{array}{l}\text { She has gone to see our cucu in Kajang } \\
(132)\end{array}$ & grandchild \\
\hline
\end{tabular}

"Cucu" means 'grandchild' in Malay language. In Malay families, they address their grandchildren as 'cucu'. Here, this term is used to emphasize the usage of kinship terms among the Malay community.

\begin{tabular}{|l|l|l|}
\hline Word & Sentence/phrase & English equivalent \\
\hline Adik & Safiah said, “Adik, do you hear me (138) & Young brother \\
\hline
\end{tabular}

The word adik means young brother, is used in Malaysia, Filipino and Indonesia, which shows that ,it is not used only by different ethnic groups in Malaysia but also by the neighboring countries.

\begin{tabular}{|l|l|l|}
\hline Word & Sentence/phrase & Meaning \\
\hline Lao puo & $\begin{array}{l}\text { My Lao Puo, Emily,'giving his wife a } \\
\text { kiss on her cheek (34) }\end{array}$ & Wife \\
\hline
\end{tabular}

"Lao puo" is a Chinese word means "wife". This word is used among all races in Malaysia The term can be used to link the reader into a multiculturalism of many ethnic groups in Malaysia .This can be seen in the novel where the word "Lao puo" is used among Indian and Malay community , as shown in the example above where Magnus is from different ethnic group call his wife as "lao poe".

\begin{tabular}{|l|l|l|}
\hline Word & Sentence/phrase & Meaning \\
\hline Merdeka & $\begin{array}{l}\text { I walked miles during the Japanese } \\
\text { Occupation, After Merdeka I looked at } \\
\text { my legs and thought (90) }\end{array}$ & \\
\hline
\end{tabular}

"Merdeka" is a Malay word means "independence day" in Malaysia. All races in Malaysia use this word "Merdeka" to describe their independence day. Regardless of the language they speak. 
c) Semantic restriction

These are local words with possible English translations but are used in a semantically restricted field, for example

\begin{tabular}{|l|l|l|}
\hline Word & Sentence/phrase & Meaning \\
\hline Bungalow & $\begin{array}{l}\text { You could be a rich man.With a } \\
\text { bungalow and servants (18) }\end{array}$ & Small house or cottage \\
\hline
\end{tabular}

"Bungalow"is a Malay word refers to a place for rich and famous people or completely separate house ,no matter how many floors it has. In general "Bungalow" has the meaning of small house or cottage in standard English .But here it shows that the Malay has taken the word from English and use it in their Malaysian language with different meaning.

\begin{tabular}{|l|l|l|}
\hline Word & Sentence/phrase & Meaning \\
\hline Outstation & $\begin{array}{l}\text { Going outstation, Madam "Yes, going } \\
\text { outstation," (83) }\end{array}$ & Remote or outlying station \\
\hline
\end{tabular}

The term refers to "being a way" by Malaysian community. In general the word "outstation" refers to "remote or outlying station" in standard English. Malays use the word during the colonial time, then consider it as part of Malay language. The sentence "Iam outstation" would show that it can be understood by Malaysian English speaking but not by standard British English

d) Cultural and culinary terms

These are words that refer to specific Malaysian cultural and culinary items that are usually alien to the English Language, for example

\begin{tabular}{|l|l|l|}
\hline Word & Sentence/phrase & Meaning \\
\hline Baju & $\begin{array}{l}\text { Bakar withdrew and emerged shortly } \\
\text { afterwards wearing a baju Melayu and a } \\
\text { white skull cap (p78) }\end{array}$ & Traditional Malay shirt \\
\hline
\end{tabular}

"Baju" refers to a "Malay shirt". It is a traditional custom of man in Malay culture.It includes of two parts: The first part is a long sleeved shirt that has a raised stiff collar. The second part is the trouser, the fabric which is used to make these two parts is a mixture of cotton and polyester or only cotton, followed by skirt as a type of decoration with the Baju The skirt either "kain sarung" made out of mix polyster or cotton or the "kain samping" made out of songket cloth. Both are folded around the waist as an important custom in Malay culture.

\begin{tabular}{|l|l|l|}
\hline Word & Sentence/phrase & Meaning \\
\hline Kopiah & $\begin{array}{l}\text { He wore a kopiah and he carried .I think it } \\
\text { was a briefcase (114). }\end{array}$ & Islamic cap \\
\hline
\end{tabular}

Is a Muslim Malay word means "skufful cap" It is worn by Muslim Malay in Malaysia and some other neighboring countries like Indonesia Singapore, southern Philippines, Brunei and southern Thailand. It is made of cotton or velvet .It has a conical shape .Some Malay men wear it in funeral or occasions like "Eid el Fitr", which is a Muslim religious holiday marks after the holy month of fasting "Ramadan" .

e) Hyponymous collocation

These include local words that have been collocated with English super ordinate terms, for example 'angsana tree', 'batik cloth' (Baskaran, 1985). 


\begin{tabular}{|l|l|l|}
\hline Word & Sentence/phrase & Meaning \\
\hline Batik shirt & $\begin{array}{l}\text { I looked as though I was wearing an } \\
\text { overly tight batik shirt (245) }\end{array}$ & Traditional Malay shirt \\
\hline
\end{tabular}

"Batik" is a Malay word refers to "waxed printing design cloth". The suffix 'shirt' is used with the local Malay term .

f) Campus / Student coinages

It indicates words that's only used by student. There is no data appear to fill in this category since it is words used by students in university and the novels doesn't have a university setting.

\section{Conclusion}

This article analyzes the use of Malaysian English lexical items in "Green Is the Color" by Lloyd Fernando .The data grouped according to the categorization methods proposed by Baskaran (2005). An amount of Malaysian English lexis used by Lloyd Fernando in his novel. It is clear that Malaysian English lexical items are different from standard English in the term of form and meaning. Some words like 'cucu' and 'adik' mean 'grandchild' and 'young brother' which come under emotional and cultural loading category can be translated into English but it will lose its cultural boundaries that's why the author insists on using these words in his novel.

Lloyd Fernando also presents patriotism by using Malaysian English when outshine to describe the independence in their national language 'Merdeka', he shows that he doesn't hesitate borrowing these local words in his English language and present it to the world .Also he shows that these words used by all races in Malaysia as a sign that Chinese and Indian in Malaysia adopt the culture of this country as a part of their culture which made them different from the other Indian and Chinese around the world.

\section{References}

Baskaran, L. (1985). The New Englishes. Jurnal Bahasa Moden. English as a World Language, 6, 69-95. Cambridge: Cambridge University Press.

Baskaran, L. (2005). A Malaysian English Primer, Aspects of Malaysian English Features. Kuala Lumpur : University of Malaya Press.

Eardley, Tom. 2014. https://www.bbc.com/news/uk-27324224

Platt, John, and Weber, Heidi (1980) English in Singapore and Malaysia : Status, Features, Functions. Kuala Lumpur : Oxford University Press

Prema, Balan.2012. The Use OF Malaysian English Lexical Items In TheWork Of Preeta Samarsan. Kuala Lumpur: University Of Malaya.

Ramakrishnan, Kamalanathan M, and Ismail, Noriah, ibid, 2007. Malaysian English Versus Standard English: Which Is Favored? MARA University of Technology (Johor) Academic Conference 2007

Sridhar, S.N., 1982. Non-native English literatures : context and relevance. In: B.B

Tongue, R.K. 1974. The English of Singapore and Malaysia. Eastern Universities Press: Singapore.

Trudgill, P. \& Hannah, J. 1982. International English: AGuide to the Varieties of Standard English. First edition.London: Arnold. 